Article

\title{
Biological Reduction of Organic Matter in Buji River Sediment (Shenzhen, China) with Artificial Oxygenation
}

\author{
Lin Che ${ }^{1}$, Wenbiao Jin ${ }^{1, *}$, Xu Zhou ${ }^{1, *}$, Chenbo Cao ${ }^{1}$, Wei Han ${ }^{1}$, Changlei Qin ${ }^{2}$, Renjie Tu ${ }^{1,3}$, \\ Yidi Chen ${ }^{1}$, Xiaochi Feng ${ }^{1}$ and Qilin Wang ${ }^{4}$
}

1 Shenzhen Engineering Laboratory of Microalgal Bioenergy, Harbin Institute of Technology (Shenzhen), Shenzhen 518055, China; chelin@hitsz.edu.cn (L.C.); cbcao@hitsz.edu.cn (C.C.); hanwei2020@hitsz.edu.cn (W.H.); renjietu@hitsz.edu.cn (R.T.); chenyidi@hit.edu.cn (Y.C.); fengxiaochi@hitsz.edu.cn (X.F.)

2 Key Laboratory of Low-Grade Energy Utilization Technologies and Systems of Ministry of Education, School of Energy and Power Engineering, Chongqing University, Chongqing 400044, China; c.qin@cqu.edu.cn

3 Educational Science Research Institute of Futian, Shenzhen 518000, China

4 Centre for Technology in Water and Wastewater Treatment, School of Civil and Environmental Engineering, University of Technology Sydney, Sydney 2007, Australia; Qilin.Wang@uts.edu.au

* Correspondence: jinwb@hit.edu.cn (W.J.); zhouxu@hit.edu.cn (X.Z.); Tel.: +86-0755-2603-3512 (W.J.); +86-755-2603-3506 (X.Z.)

Received: 31 October 2020; Accepted: 18 December 2020; Published: 21 December 2020

\begin{abstract}
In this work, artificial oxygenation treatment (pure oxygen aeration or oxygen enriched water injection) combined with the introduction of exogenous microorganisms was employed to purify urban river sediment for the first time. Results showed that the developed in situ remediation strategy could increase the dissolved oxygen (DO) concentration and oxidation-reduction potential (ORP) value of the sediments. Benefiting from the increase of $\mathrm{DO}$ concentration, the bacterial diversity was enhanced. The highest removal efficiencies of organic matter were $18.4 \%$ and $22.3 \%$ through pure oxygen aeration and oxygen enriched water injection, respectively. More importantly, overlying water quality was not affected. By comparison, oxygen enriched water injection treatment could achieve better performance on sediment purification. Introducing exogenous microorganisms further reduced the organic matter content of the sediment. In short, the current work not only proposed a promising strategy for controlling urban river sediment pollution, but also provided novel insight for the understanding of river sediment containing highly concentrated organic matter.
\end{abstract}

Keywords: river sediment; dissolved oxygen; oxygenation; biological reduction; organic pollutant

\section{Introduction}

Currently, sediment pollution is a grave problem facing humankind, which seriously threatens the eco-balance of the aquatic environment [1]. In general, various contaminants, such as heavy metals and organic substances, enter into water bodies via atmospheric deposition, precipitation, and wastewater discharging, becoming deposited and enriched in the sediment, thereby resulting in sediment pollution [2,3]. The sorption of organic pollutants by sediments is driven by hydrophobic interactions, including the entropic effect of the aqueous phase and non-specific interactions between organic pollutants and sediment organic matter [4]. River sediment usually contains gelatinous humus, various concentrations of granular kerogen, and black carbon substances, all of which exhibit non-partitioning phenomena, causing adsorption of a considerable amount of organic pollutants [5]. Noticeably, once 
the sedimentary contaminants are released into water, the aquatic eco-balance is inevitably disrupted. However, conventional river improvement projects usually only pay attention to the overlying water and surrounding greenery, but ignore the remediation of polluted sediment [6-8]. The contaminated sediment, without proper management, becomes a continuous source of endogenous pollution for the river. Therefore, more effort should be made to study the treatment of polluted sediment.

Over the past few decades, two typical control strategies have been developed for treating polluted sediments, namely ex situ remediation and in situ remediation [9]. In ex situ remediation, the polluted sediments are usually dredged from the water body and then treated in different ways, such as sending them to a sanitary landfill or burning them [10]. Yet a number of studies have shown that dredging projects could have systemic difficulties in achieving the targeted cleanup threshold and cause damage to the benthic ecosystem as a converse effect. In several countries, such as USA, Netherlands, and Sweden, a large amount of capital investment has been allocated to dredging projects; however, most of the reported ex situ remediation processes were proved to be ineffective in terms of economic, environmental, and technical goals [11]. On the other hand, in situ remediation refers to the utilization of physical, chemical, or biological methods to decrease the contamination level of the polluted sediment, without taking the sediment out of the water body [12-14]. According to the principle of the method, in situ remediation could be divided into in situ chemical treatment, in situ stabilization treatment, and in situ biological treatment $[8,15]$. In comparison with ex situ remediation, in situ remediation has several advantages, such as being low cost and easy [16]. Bonardi et al. (2007) [17] performed an in situ forced aeration test in the Arsenale shipyard dock basin of the Venice Lagoon, Italy. Besides stimulating the aerobic bacterial communities and the biodegradation of sedimentary contaminants, an effective removal of heavy metals was also observed in his study [17]. Murphy et al. (1988) [18] reported that the addition of calcium nitrate was useful for precipitating around 79\% of the pore phosphorus from the sediment of the Biwa Lake in Japan. Payne et al. (2019) [19] found the combination of microbial bioaugmentation and enhanced sorption was effective for in situ treatment of polychlorinated biphenyls in Virginia, with the concentration of polychlorinated biphenyls and coplanar congeners reduced by $52 \%$ and $80 \%$, respectively. Owing to the simplicity and the relatively lower demand in capital investment, using in situ remediation for the treatment of contaminated river sediment is especially favored in developing countries [20].

Among all the proposed in situ remediation methodologies, in situ biological treatment was regarded as one of the most promising options [21]. Diaz et al. (2000) [22] isolated a community, including five petroleum-degrading microorganisms, that was capable of treating petro polluted sediments over a wide range of salinity. Bose et al. (2020) [23] constructed an in situ sediment microbial fuel cell, which utilized the inherent activity of microorganisms to generate voltage gradients, for the degradation of sedimentary pollutants in Rajasthan, India. For the in situ bioremediation of nitrobenzene-contaminated sediments, a novel bio-reactive capping barrier composed of a polysulfide/granular-activated carbon hybrid membrane immobilized with microorganisms was developed by Wang et al. (2014) [24]. It is widely known that the organic pollutants from sediment could be degraded through endoenzymes or exoenzymes produced by microorganisms, which were mainly affected by nutrients supply and electron receptors [25]. During the microbial aerobic decomposition process, most organic substances can be rapidly degraded into $\mathrm{H}_{2} \mathrm{O}$ and $\mathrm{CO}_{2}$ when adopting $\mathrm{O}_{2}$ as electron receptor [14]. Hence, oxygen aeration was a common and useful treatment for sediment pollution. Additionally, the development a novel in situ biological treatment using exogenous microorganisms aroused widespread interest for treatment of sediment pollution [26].

Based on the above background and taking sediment from the Buji River (Shenzhen City, China) as the research object, a test for the reduction of organic pollutants in river sediment was carried out by oxygenation and with the introduction of exogenous microorganisms. The pure oxygen aeration and oxygen enriched water injection were selected as the artificial oxygenation methods. Furthermore, the physical-chemical properties of the sediment were analyzed. 


\section{Materials and Methods}

\subsection{Chemicals and Materials}

The sediment was obtained from an upstream section of the Buji River (Shenzhen, China) (Figure 1) (E 114.11, N 22.59). A $30 \mathrm{~m}$ river section was selected as the sampling area and it is $12 \mathrm{~m}$ wide with a water depth of $31.6 \mathrm{~cm}$. The sediment was collected using a surface layer sampling strategy with a $21.8 \mathrm{~cm}$ depth. The sampling interval was $10 \mathrm{~m}$. Each section had three sampling points (both sides and the middle of the river), with a total of 9 sampling points for the 3 sections. The samples were collected by manual excavation to a depth of about $0-15 \mathrm{~cm}$ and then sealed and preserved separately. DNA extraction kit, Ex-TaqDNA polymerase, and primers (namely $341 \mathrm{f}$ and R518) were purchased from Bio Teke Co., Ltd. (Beijing, China).

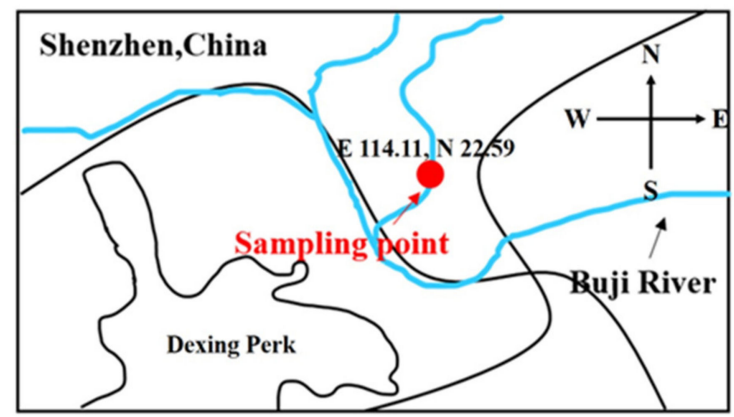

Figure 1. Coordinate system for the sampling.

\subsection{Pure Oxygen Aeration Treatment}

The pure oxygen aeration treatment was performed in a glass bowl, and a simple diagram of the process is displayed in Figure 2a. Typically, thicknesses of the sediment and overlying water were 10 and $25 \mathrm{~cm}$, respectively. The intermittent aeration was conducted for $12 \mathrm{~h}$ (8 a.m.-8 p.m.), and lasted approximately 105 days. The oxygen flow was set as $40 \mathrm{~mL} / \mathrm{min}$ based on preliminary experimental results. After 105 days, exogenous microorganisms were added into the reaction system, and the dosing amount accounted for $0.3 \%$ of the total sediment volume. A control treatment without aeration was also carried out. Samples were collected from the sediment surface layer $(0-5 \mathrm{~cm})$ at selected times for further analysis.
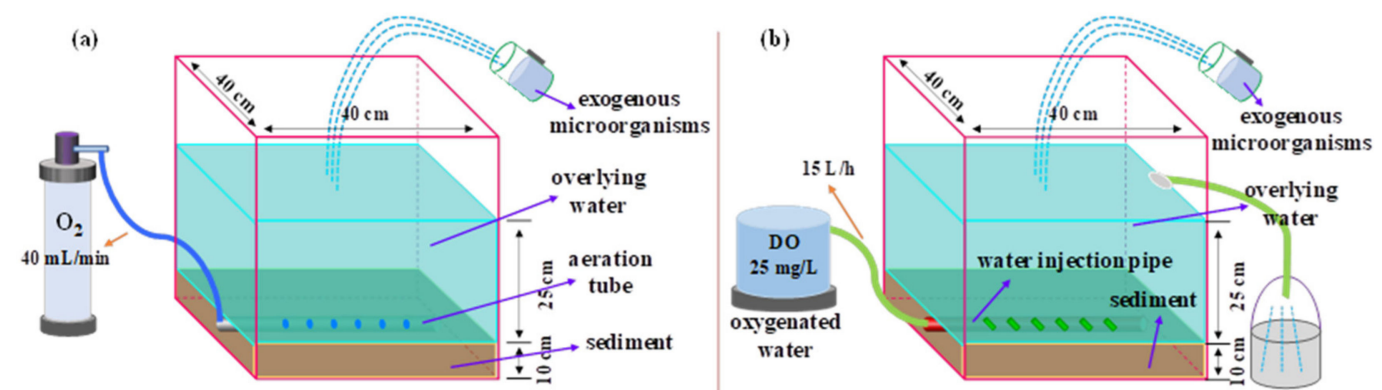

Figure 2. Schematic diagrams of (a) pure oxygen aeration treatment and (b) oxygen enriched water injection treatment.

\subsection{Oxygen Enriched Water Injection Treatment}

The oxygen enriched water injection treatment was similar to the pure oxygen aeration treatment: a diagram of the process is presented in Figure 2b. According to preliminary experimental results, dissolved oxygen (DO) concentration and flow rate of oxygen enriched water were $25 \mathrm{mg} / \mathrm{L}$ and $15 \mathrm{~L} / \mathrm{h}$, respectively. Other steps were in accord with those of the pure oxygen aeration treatment. The sediment in the control test was treated by injecting ordinary water. 


\subsection{Physical-Chemical Properties of Water and Sediment}

The suspended substances (SS) in water were measured by a simple gravimetric method [27]. The $\mathrm{COD}_{\mathrm{Cr}}$ (chemical oxygen demand) was determined by using a conventional dichromate method [28]. DO concentration was monitored via a portable dissolved oxygen meter (HACH YSI550A, America). Oxidation-reduction potential (ORP) of sediment was analyzed by a portable ORP detector (HACH HQ40D, America). The $\mathrm{pH}$ was measured by a portable $\mathrm{pH}$ meter (HACH HQ11D, America). The water content in the sediment was determined by heating at $105^{\circ} \mathrm{C}$ for $24 \mathrm{~h}$, while the organic matter content in the sediment was measured through calcination at $550^{\circ} \mathrm{C}$ for $4 \mathrm{~h}$.

\subsection{Determination of the Total Bacterial Count}

The plate count method was employed to determine the total bacteria count of the sediment samples [29]. First, $10.0 \mathrm{~g}$ of sample were put into $90 \mathrm{~mL}$ of sterile water in an ultra-clean bench. The samples were diluted to different concentrations of bacterial suspension and fully shaken to distribute the microorganisms evenly. Then, beef extract peptone medium plates with bacterial suspension were placed upside down in a $37^{\circ} \mathrm{C}$ constant temperature incubator; after $48 \mathrm{~h}$ the numbers of colonies were counted.

\subsection{PCR-DGGE Assays}

The bacterial community structures of the sediment were analyzed by PCR-DGGE assays [30]. The DNA was extracted using Biotech's soil genomic DNA rapid extraction kit. The primers and reaction conditions used for PCR amplification are shown in Table 1.

Table 1. The primers and reaction conditions for the PCR amplification.

\begin{tabular}{clr}
\hline Primer Names & \multicolumn{1}{c}{ Primer Sequences } & \multicolumn{1}{c}{ Reaction Conditions } \\
\hline \multirow{3}{*}{$341 \mathrm{f}$} & $5^{\prime}$-CGCCCGCCGCGCGCGGCGGGCGGGG & \multicolumn{1}{c}{ Denaturation at $94^{\circ} \mathrm{C}$ for $10 \mathrm{~min} ;$} \\
& CGGGGGCACGGGGGCCCTACGGGAGG & 30 standard cycles: denaturation at $94^{\circ} \mathrm{C}$ for 1 min, annealing at \\
R518 & CAGCAG-3' & $55^{\circ} \mathrm{C}$ for $1 \mathrm{~min}$, extension at $72{ }^{\circ} \mathrm{C}$ for 1 min; extension at $72{ }^{\circ} \mathrm{C}$ for \\
& $5^{\prime}$-ATTACCGCGGCTGCTGG-3' & 10 min after the end of the cycle. \\
\hline
\end{tabular}

\subsection{DGGE Analysis}

The DGGE spectrum was analyzed by the Gel Pro Analyzer 4.0 for data analysis. The clustering method was used to analyze the similarity of the DGGE patterns of the samples. Sorensen's coefficient calculation formula is shown in Formula (1):

$$
\mathrm{SD}=\left(2 \mathrm{n}_{\mathrm{AB}}\right) /\left(\mathrm{n}_{\mathrm{A}}+\mathrm{n}_{\mathrm{B}}\right)
$$

where SD is Sorensen's similarity coefficient; $n_{A}$ is the number of strips of sample $A ; n_{B}$ is the number of bands of sample $B$; and $n_{A B}$ is the number of bands shared by samples $A$ and $B$.

The diversity analysis Shannon index calculation is seen in Formula (2):

$$
\mathrm{H}=-\sum_{i=1}^{s} P i \times \log P i
$$

where $\mathrm{H}$ is the Shannon biodiversity index; $P i$ is the relative brightness of a certain band in the sample in the total band; and $s$ is the total number of bands in the sample. 


\subsection{Mathematical Model}

It is well known that the degradation rate is closely related to organic matter content and microbial biomass during the process of organic matter biodegradation in sediment. Therefore, a mathematical model was used to fit the degradation process according to the following equation:

$$
\mathrm{dC} / \mathrm{dt}=-\mathrm{kC}\left(\mathrm{C}_{0}-\mathrm{C}\right)
$$

where $\mathrm{C}_{0}$ and $\mathrm{C}$ were organic matter concentrations at initial and time $\mathrm{t}$, respectively, and $\mathrm{k}$ is the apparent rate constant. MATLAB software was used for solving the equation.

\section{Results and Discussion}

\subsection{Physical-Chemical Properties of Sediment}

The original physical-chemical properties of sediment from the Buji River are shown in Table 2. The initial $\mathrm{pH}$ of the sediment was about 7.22, indicating that the sediment showed slight alkalinity. Moreover, the ORP of $-172 \mathrm{mV}$ suggests a relatively strong reducing environment, which might be attributed to the existence of many organic pollutants and reducing substances in the sediment [31]. Noticeably, the organic matter content of the sediment was as high as $157.1 \mathrm{~g} / \mathrm{kg}$, revealing that the sediment of the Buji River is seriously polluted [32]. In addition, the water content of sediment reached $69.6 \%$.

Table 2. The physical-chemical properties of the sediment from the Buji River. ORP: oxidation-reduction potential.

\begin{tabular}{ccccc}
\hline Sampling Point & $\mathbf{p H}$ & Water Content & ORP $(\mathbf{m V})$ & Organic Matter Content $(\mathrm{g} / \mathbf{k g})$ \\
\hline $\mathrm{A}^{1-1}$ & 7.32 & $67.1 \%$ & -165 & 153.3 \\
$\mathrm{~A}^{1-2}$ & 7.18 & $64.2 \%$ & -179 & 160.2 \\
$\mathrm{~A}^{1-3}$ & 7.23 & $74.7 \%$ & -163 & 145.8 \\
$\mathrm{~B}^{1-1}$ & 7.20 & $80.0 \%$ & -168 & 149.3 \\
$\mathrm{~B}^{1-2}$ & 7.09 & $68.8 \%$ & -187 & 173.7 \\
$\mathrm{~B}^{1-3}$ & 7.16 & $70.3 \%$ & -172 & 137.7 \\
$\mathrm{C}^{1-1}$ & 7.35 & $64.0 \%$ & -159 & 150.5 \\
$\mathrm{C}^{1-2}$ & 7.17 & $66.1 \%$ & -181 & 173.2 \\
$\mathrm{C}^{1-3}$ & 7.28 & $71.4 \%$ & -172 & 170.7 \\
\hline average value & 7.22 & $69.6 \%$ & -172 & 157.1 \\
\hline
\end{tabular}

\subsection{Quality of Overlying Water}

In general, the sediment aeration process impacts the quality of the overlying water. Thus, the quality of the overlying water was estimated. Figure 3a shows the changes in the SS from the overlying water in the given time frame. In contrast with the SS of the control, the SS of the group with pure oxygen aeration treatment was higher, which was mainly due to the disturbance effect of oxygen [33]. Nevertheless, the SS value was still less than $50 \mathrm{mg} / \mathrm{L}$ after the pure oxygen aeration treatment. As depicted in Figure $3 \mathrm{~b}$, no striking differences were observed in the SS of the overlying water between the oxygen enriched water injection treatment and that of the control. Visibly, the SS for the oxygen enriched water injection treatment was lower than that of with the pure oxygen aeration treatment.

Normally, aerobic organic pollutants and inorganic reducing substances would be released into the overlying water from the sediment. Hence, an increasing trend of $\mathrm{COD}_{\mathrm{Cr}}$ concentration was found in all groups during the early period. It could be seen from Figure $3 c$, that $\mathrm{COD}_{\mathrm{Cr}}$ concentration of the overlying water for the pure oxygen aeration treatment decreased with the extension of processing time. Benefiting from the increase of dissolved oxygen after the pure oxygen aeration treatment, large amounts of organic matter could be degraded by aerobic microorganisms, thereby resulting in the reduction of $\mathrm{COD}_{\mathrm{Cr}}$ concentration [34]. In the control treatment, $\mathrm{COD}_{\mathrm{Cr}}$ concentration of the overlying 
water reached a maximum of $73 \mathrm{mg} / \mathrm{L}$ at 35 days, and then realized a dynamic balance. As illustrated in Figure $3 d, C_{C D}$ concentration of the overlying water for all treatments continuously declined with the prolongation of treatment time. As expected, during the water injection treatment process, the overlying water body was diluted by the injection of fresh water, so the COD $\mathrm{Cr}_{\text {concentration of }}$ overlying water was reduced.
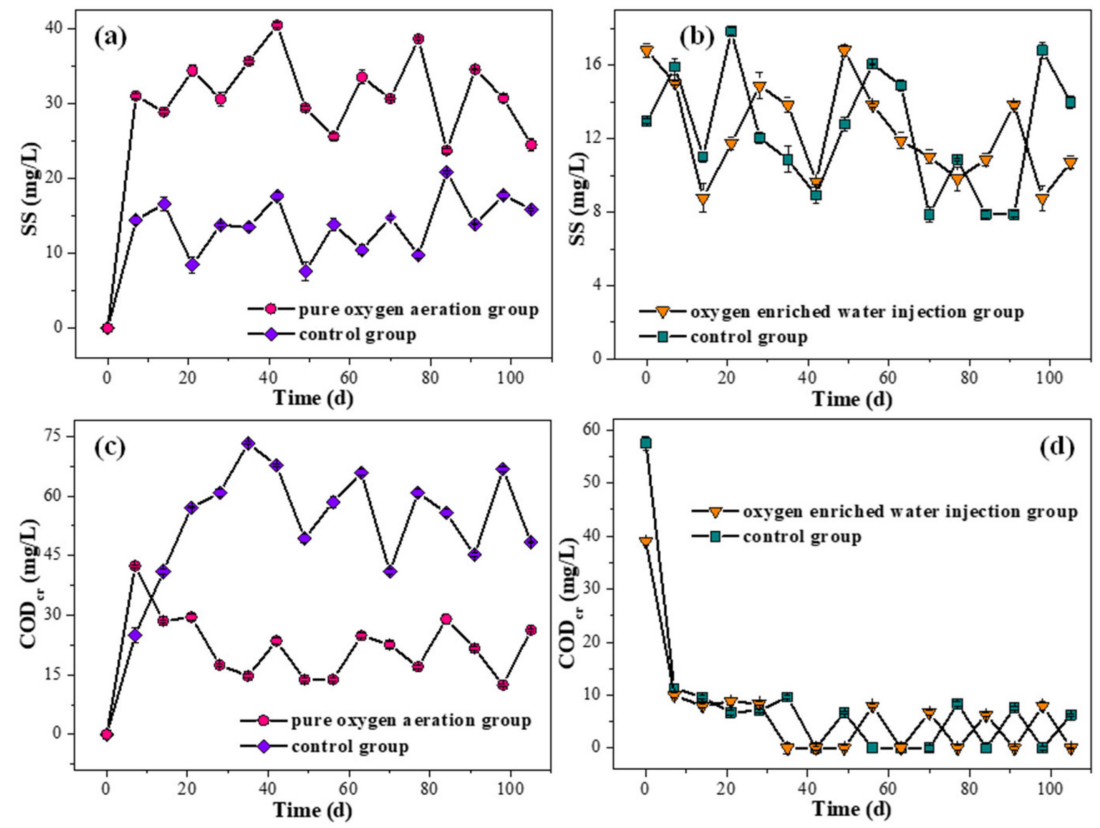

Figure 3. The effects of (a) pure oxygen aeration treatment and (b) oxygen enriched water injection treatment on the suspended solids (SS) concentration in the overlying water; the effects of (c) pure oxygen aeration treatment and (d) oxygen enriched water injection treatment on chemical oxygen demand $\left(\mathrm{COD}_{\mathrm{Cr}}\right)$ concentration in the overlying water.

\subsection{Characteristic Change of Sediment}

Generally, after a pure oxygen aeration treatment, the oxidation of the reducing sulfide in sediment would produce $\mathrm{H}^{+}$. Thus, as shown in Figure $4 \mathrm{a}$, a declining trend in the $\mathrm{pH}$ value of sediment was observed. Meanwhile, anaerobic breakdown of organic matter in the sediment would generate organic acids, which led to a decline in the $\mathrm{pH}$ value of control group. Figure $4 \mathrm{~b}$ shows that the $\mathrm{pH}$ value of these two treatment samples reduced, which was mainly ascribed to oxidation of the reducing sulfide in the sediment [35]. In comparison with pure oxygen aeration treatment, the reduction extent of the $\mathrm{pH}$ in the samples treated with water injection was less, which was mainly due to the dilution effect of the water injection.

In the reaction system, oxygen was primarily consumed by reducing substances and microorganisms. The results of DO concentration changes are displayed in Figure 4c. DO concentration of the sludge-water interface reduced in the control treatment samples over time, then reached a low level and remained stable after 7 days. After aeration of sediment, DO concentration rapidly increased at the beginning of the experiment. Subsequently, DO concentration was stable after 15 days. During this stage, oxygen consumption of the reducing substances through degradation and oxygen supplementation achieved a balance. After 55 days, DO concentration showed an upward trend, which resulted from the reduction by the reducing substances. As depicted in Figure $4 d$, injecting oxygen enriched water could effectively improve DO concentration of the sludge-water interface [36], whereas injecting ordinary water could not inhibit the reduction of the DO concentration.

ORP presents a positive correlation with DO concentration [37]. A high ORP value is beneficial for water quality improvement. It can be observed from Figure $4 \mathrm{e}, \mathrm{f}$ that both pure oxygen aeration 
and oxygen enriched water injection increased the ORP value of the sediment. More importantly, the results of ORP were coincident with that of DO concentration.
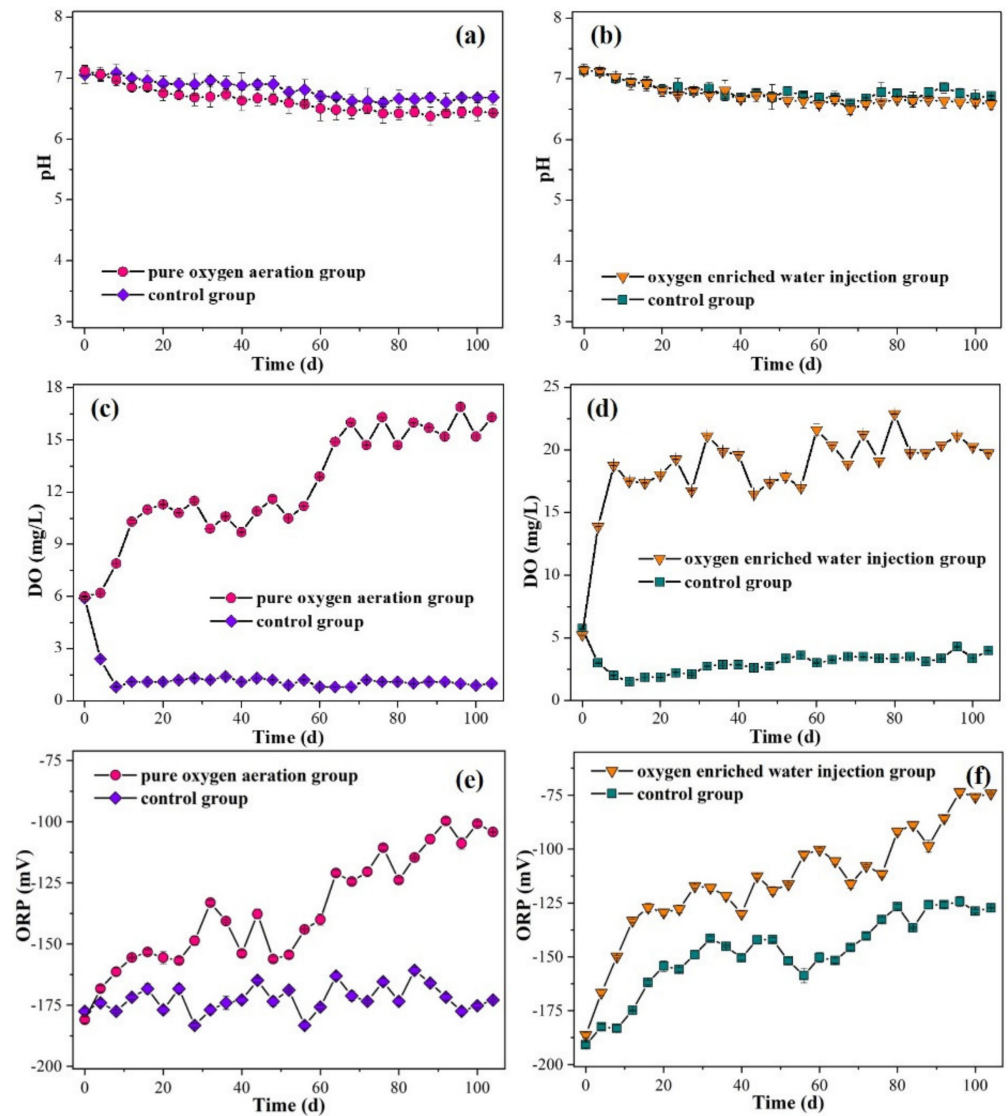

Figure 4. The effects of (a) pure oxygen aeration treatment and (b) oxygen enriched water injection treatment on the $\mathrm{pH}$ of the sediment; the effects of (c) pure oxygen aeration treatment and (d) oxygen enriched water injection treatment on the dissolved oxygen (DO) concentration in the sediment; the effects of (e) pure oxygen aeration treatment and (f) oxygen enriched water injection treatment on the ORP in the sediment.

Generally speaking, the organic compound content of sediment could reflect its pollution condition [26]. As illustrated in Figure 5a, the pure oxygen aeration treatment dramatically reduced the organic compound content of the sediment. The highest removal efficiency was $18.4 \%$, which was 4.6 times higher than that of the control treatment. Furthermore, the changes of organic compound content in the sediment after the injection of water are displayed in Figure 5b. It was found that organic compound content was significantly $(p<0.05)$ reduced by injecting oxygen enriched water, its highest removal efficiency of organic compound reached $22.3 \%$, which increased by $10.3 \%$ as compared to that of the control treatment. In addition, it was noted that the oxygen enriched water injection treatment was better than the pure oxygen aeration treatment in reducing organic compound content, which could be attributed to the fact that some organic compounds escaped from the reaction system due to continuous water injection. This result was slightly lower than that found in a previous study by Jiang et al. (2010) [38], who used a microbial fuel cell for removing organic matter from freshwater sediment and achieved a removal efficiency of $28.3 \%$. In comparison with the microbial fuel cell treatment, the developed treatment method in the current work is simpler and more feasible. 

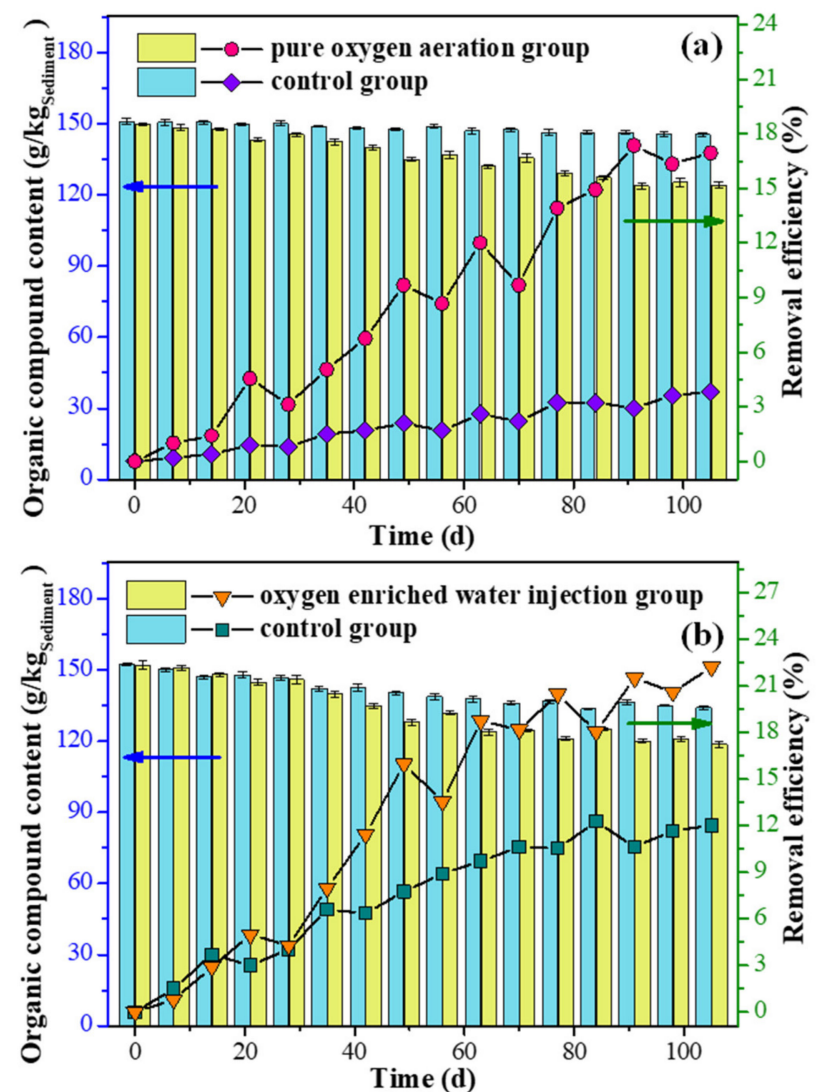

Figure 5. (a) The effects of the pure oxygen aeration treatment on the organic compound content in the sediment, and (b) the effects of the oxygen enriched water injection treatment on the organic compound content in the sediment.

In order to investigate biodegradation behaviors of organic matter in sediment, a mathematical model was employed to fit the degradation process. As shown in Figure 6a, the correlation coefficients (R2) of the samples with pure oxygen aeration and the control treatment were 0.9363 and 0.8162 , respectively. The calculated $\mathrm{k}$ values of the samples of pure oxygen aeration and the control treatment were 0.0007472 and 0.0005931 , respectively, indicating that the pure oxygen aeration treatment could remarkably improve the degradation rate of organic matter. To further predict degradation of organic matter in sediment, the reaction time was extended to 300 days in the model. As depicted in Figure 6b, organic matter content was basically stable with increasing pure oxygen aeration time, suggesting that residual organic matter in sediment was quite recalcitrant to degradation. In the control sample, the organic matter content reached a steady state finally, but with a longer time course. It can be seen from Figure $6 \mathrm{c}$ that the R2 of the sample with the injection of oxygen enriched water and that of the control sample were 0.9703 and 0.8473 , respectively. Meanwhile, the k value of sample with the injection of oxygen enriched water was as high as 0.0007623 , while the $\mathrm{k}$ value of the control sample was only 0.0004142 . Figure $6 \mathrm{~d}$ shows that the organic matter content in the control sample reached a steady state after 180 days, whereas it took 80 days to achieve the stable organic matter content in the experimental group. In summary, compared with the pure oxygen aeration treatment, the oxygen enriched water injection treatment was more effective in improving sediments. 

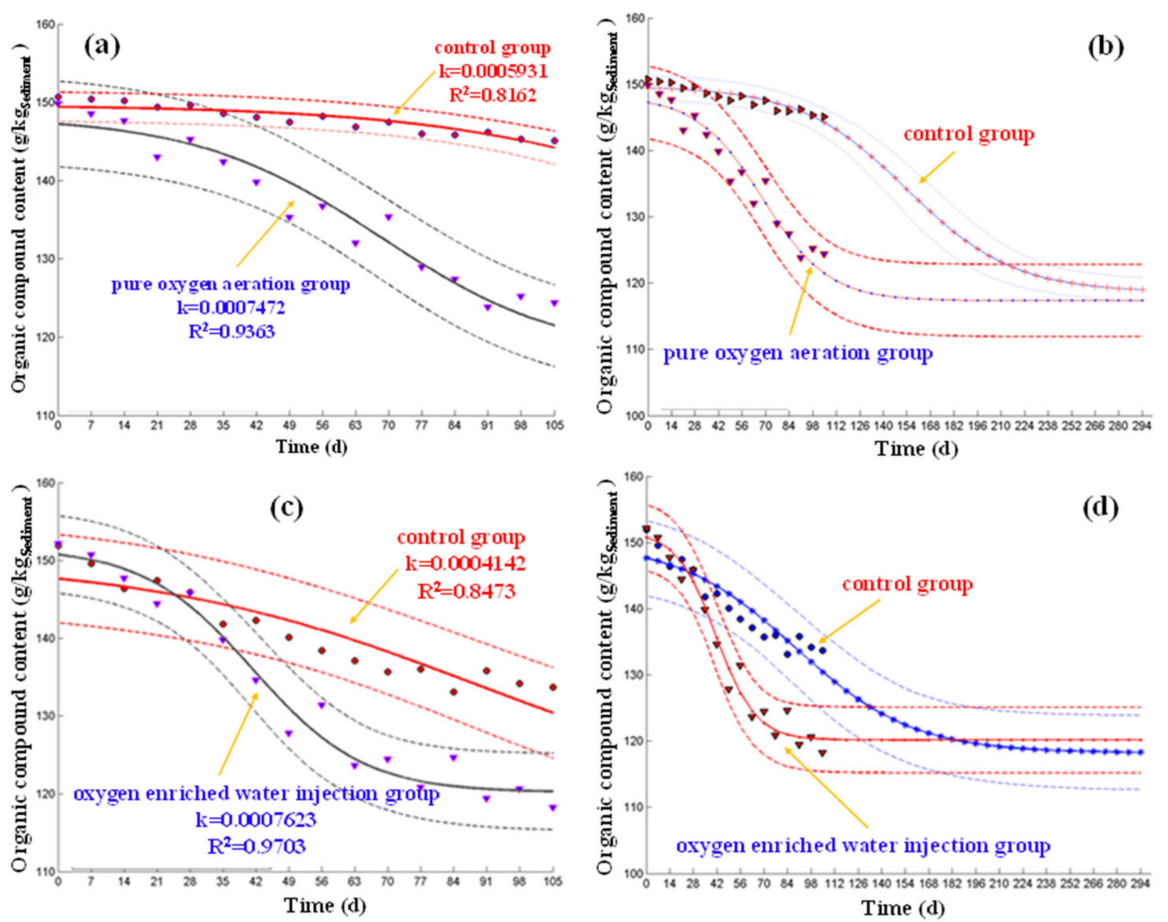

Figure 6. (a) The fitting model and (b) prediction of organic compound content in sediment during pure oxygen aeration treatment; (c) the fitting model and (d) prediction of organic compound content in sediment during oxygen enriched water injection treatment.

\subsection{Effect of Introducing Exogenous Microorganisms}

The above results indicate that both pure oxygen aeration treatment and oxygen enriched water injection treatment exhibited a limited ability to remove organic matter from sediment. Therefore, in order to further decrease the organic matter content of sediment, exogenous microorganisms were introduced into reaction system after 105 days.

Generally, the addition of exogenous microorganisms inevitably leads to the increase of oxygen consumption [39]. As expected, Figure 7a,b shows that the DO concentration had a decreasing trend after the introduction of exogenous microorganisms. In addition, as illustrated in Figure $7 \mathrm{c}, \mathrm{d}$, the variation trends of the ORP in the sediment were consistent with that of the DO concentration.

Figure 8 shows the changes in the organic matter content after the introduction of exogenous microorganisms. The addition of exogenous microorganisms decreased the organic matter content of the sediment to some degree, indicating that introducing exogenous microorganisms was effective in removing organic matter content from the sediment. However, the removal efficiency was not high enough. The reason might be that the environments of the simulated reaction system were unable to meet the conditions for the survival of exogenous microorganisms, thereby inhibiting the biological activity. 

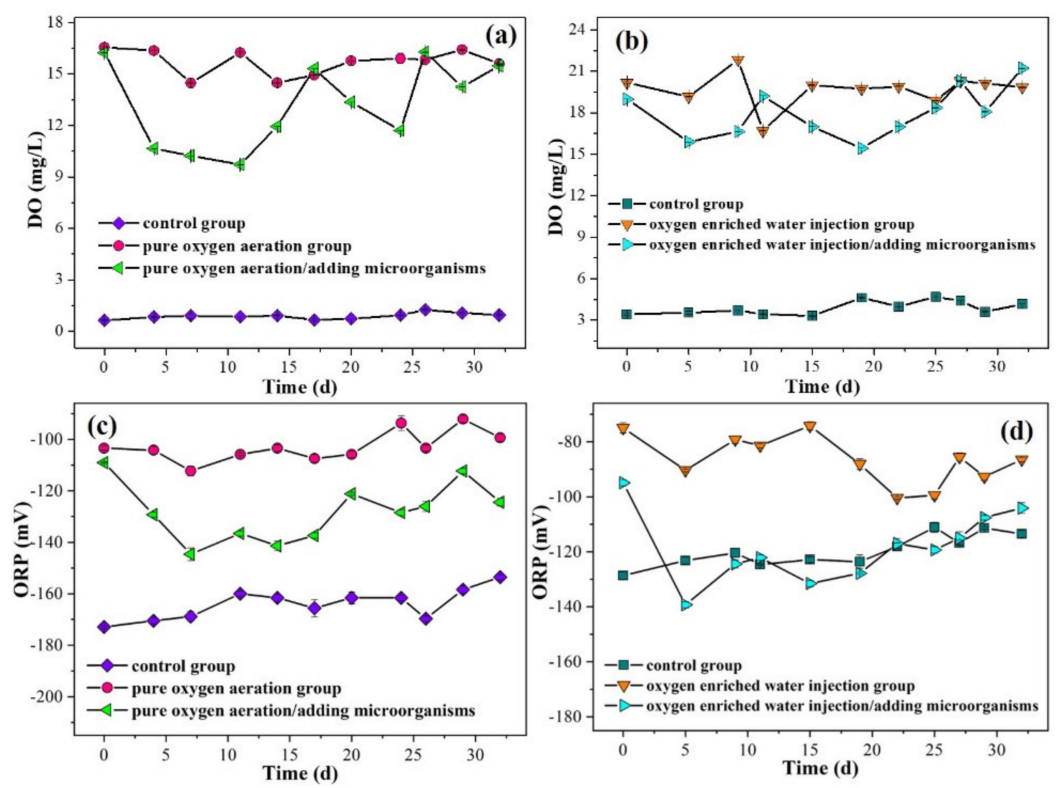

Figure 7. The changes of the DO concentration in the sediment during (a) pure oxygen aeration treatment and (b) oxygen enriched water injection treatment after adding microorganisms; the changes of the ORP in the sediment during (c) pure oxygen aeration treatment and (d) oxygen enriched water injection treatment after adding microorganisms.
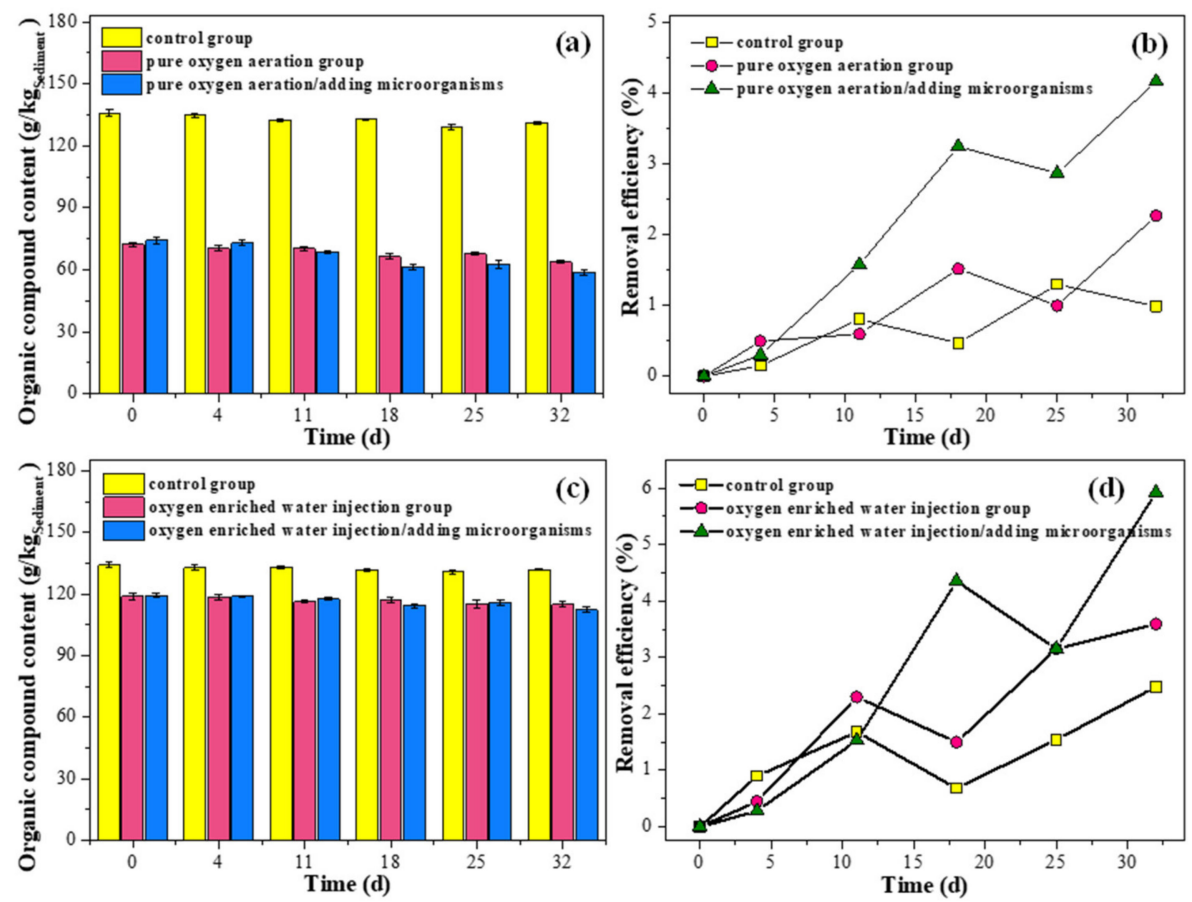

Figure 8. The changes of the organic compound content in the sediment during (a) pure oxygen aeration treatment and (c) oxygen enriched water injection treatment after adding microorganisms; removal efficiencies of the organic compounds during (b) pure oxygen aeration treatment and (d) oxygen enriched water injection treatment after adding microorganisms.

\subsection{Change of Bacterial Community}

The removal of organic matter was closely related to the bacterial community in the sediment. Hence, the changes to the bacterial community in the sediment were also explored. As shown in Figure $9 \mathrm{a}, \mathrm{b}$, both pure oxygen aeration and oxygen enriched water injection increased the total counts of bacteria in the sediment, which was instrumental in the biodegradation of organic matter. Nevertheless, 
the total counts of bacteria showed a decreasing trend at a later stage, which might be related to the reduction in available organic matter [40]. Figure 9c,d shows that the total count of bacteria had an inversed V-shape change tendency after the introduction of exogenous microorganisms. The results of the DNA extraction are presented in Figure 10a. The sizes of the DNA fragments were $23 \mathrm{~kb}$, which is the same as that of the bacterial genomic DNA, proving that the extracted total DNA belonged to relatively complete bacterial genomic DNA. The $16 \mathrm{~S}$ rDNA of the bacteria was amplified by PCR with the extracted total DNA as a template, and a $663 \mathrm{bp}$ fragment was amplified and is shown in Figure $10 \mathrm{~b}$. The results of the DGGE profile are displayed in Figure 10c. It was observed that there were fewer bands and their brightness was lower in control samples, suggesting that the species and amounts of bacteria were relatively small. After the pure oxygen aeration treatment or oxygen enriched water injection treatment, the number of bands was increased with higher brightness, demonstrating that the species and amounts of bacteria in the sediment were increased significantly [41]. The Shannon-Weiner index $(\mathrm{H})$ was calculated according to the results of the DGGE profile. Generally speaking, the higher the $\mathrm{H}$ value, the higher the biodiversity [42]. As illustrated in Figure 10d, the H values of A2 and B2 were higher than that of A1 and B1, indicating that bacterial diversity in the sediment increased after pure oxygen aeration treatment or oxygen enriched water injection treatment. Meanwhile, the addition of exogenous microorganisms further improved the bacterial diversity of sediment. The high bacterial diversity was more beneficial to decrease the organic matter content of the sediment. These findings were consistent with the above-mentioned results.
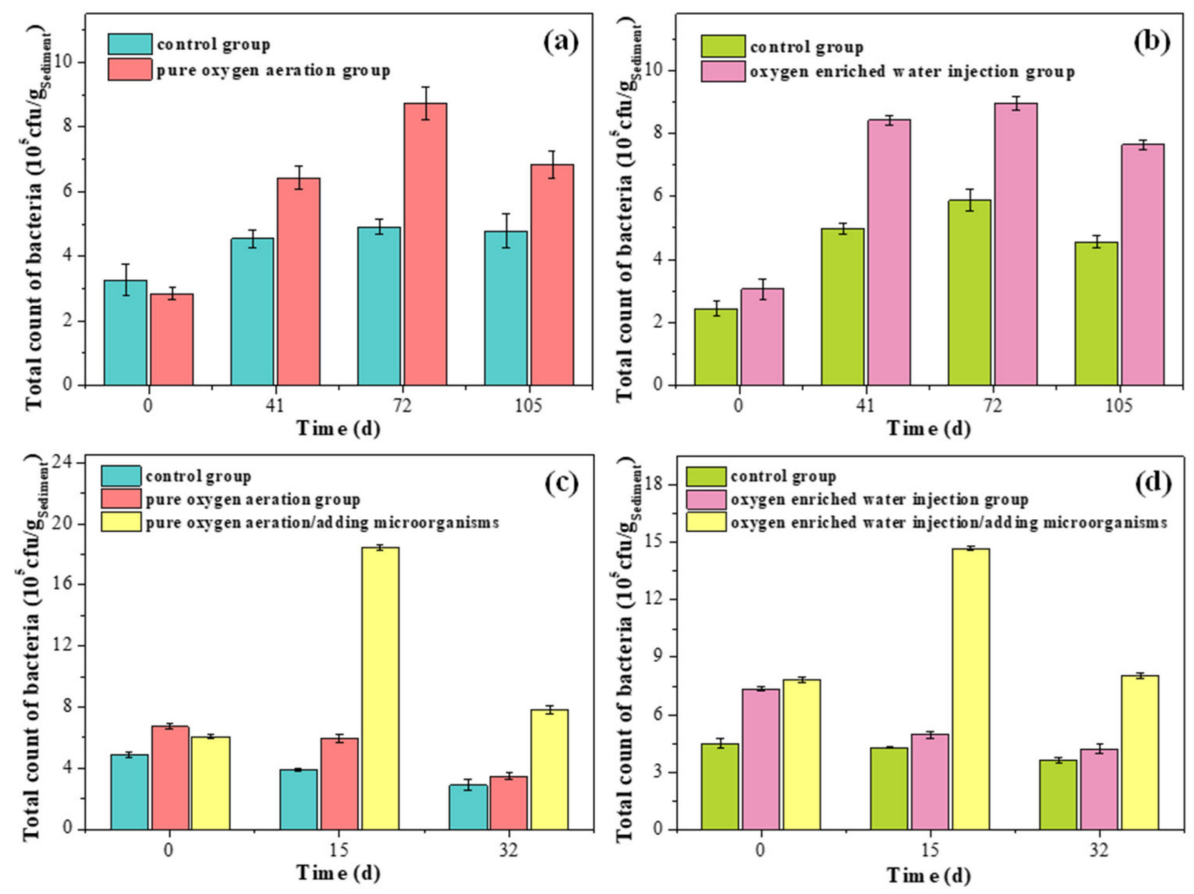

Figure 9. The effects of (a) pure oxygen aeration treatment and (b) oxygen enriched water injection treatment on the total count of bacteria in the sediment; $(\mathbf{c}, \mathbf{d})$ the effects of adding microorganisms on the total count of bacteria in the sediment. 


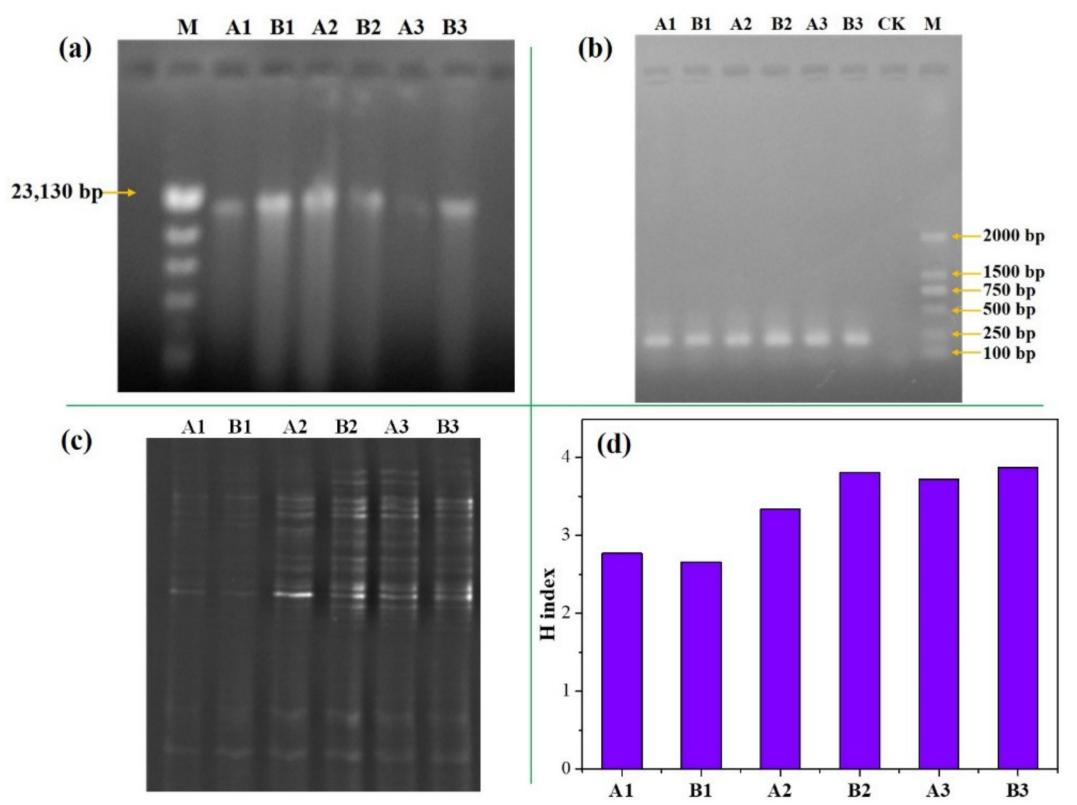

Figure 10. (a) The results of the total DNA extraction; (b) the results of agarose gel electrophoresis detection; (c) the DGGE profile; and (d) the diversity index of bacteria in the sediment. (A1: the control sample in the pure oxygen aeration treatment, B1: the control sample in the oxygen enriched water injection treatment, A2: the sample with the pure oxygen aeration treatment, B2: the sample with the oxygen enriched water injection treatment, A3: the sample with the pure oxygen aeration treatment coupled with the addition of exogenous microorganisms, B3: the sample with the oxygen enriched water injection treatment coupled with the addition of exogenous microorganisms).

\section{Conclusions}

In conclusion, the pure oxygen aeration treatment (or oxygen enriched water injection treatment) coupled with the addition of exogenous microorganisms was used to purify river sediment from the Buji River in Shenzhen city, China. Both the pure oxygen aeration treatment and oxygen enriched water injection treatment could increase the DO concentration and ORP value of the sediment. Additionally, the bacterial diversity in the sediment became more complex after pure oxygen aeration treatment and oxygen enriched water injection treatment. As expected, the organic matter content of the sediment was remarkably decreased via both aerating methods. More importantly, these two aerating methods had no obvious impact on the quality of the overlying water. By comparison, the oxygen enriched water injection treatment achieved better performance than that of the pure oxygen aeration treatment on sediment improvement. It was also found that the introduction of exogenous microorganisms further reduced the organic matter content of the sediment. In summary, the current results offer novel insight into the treatment of river sediment containing highly concentrated organic matter.

Author Contributions: Conceptualization, L.C., W.J. and X.Z.; Data curation, L.C., W.J., X.Z., and W.H.; Methodology, L.C., W.J., X.Z., W.H. and X.F.; Sample collection, L.C., C.C., C.Q., and R.T.; Investigation, L.C., C.C., Y.C., X.F., and Q.W.; Formal analysis, L.C., C.C. and X.Z.; Writing-original draft, L.C.; Writing-review and editing, L.C., W.J., X.Z., and W.H.; Funding acquisition, W.J. and X.Z.; Supervision, L.C.; C.C., W.H. and X.Z.; Validation, W.H., Q.W. and R.T.; All authors have read and agreed to the published version of the manuscript.

Funding: This work was supported by the National Natural Science Foundation of China (No.51878215), Natural Science Foundation of Guangdong Province, China (2018A030313185), Key Areas Research and Development Program of Guangdong Province, China (2019B110205001), Demonstration Project for Marine Economic Development in Shenzhen to Dr. Zhangli HU, China's State Oceanic Administration, and Shenzhen Science and Technology Innovation Project (KJYY20171011144235970).

Conflicts of Interest: The authors declare no conflict of interest. 


\section{References}

1. Hagemann, N.; Schmidt, H.; Kägi, R.; Böhler, M.; Sigmund, G.; Maccagnan, A.; McArdell, C.S.; Bucheli, T.D. Wood-based activated biochar to eliminate organic micropollutants from biologically treated wastewater. Sci. Total Environ. 2020, 730, 138417. [CrossRef] [PubMed]

2. Chen, Q.; Chen, P. Changes in the heavy metals and petroleum hydrocarbon contents in seawater and surface sediment in the year following artificial reef construction in the Pearl River Estuary, China. Environ. Sci. Pollut. R 2020, 27, 6009-6021. [CrossRef] [PubMed]

3. Baloun, J.; Adam, V.; Trnkova, L.; Beklova, M.; Svobodova, Z.; Zeman, L.; Kizek, R. Complexes of glutathione with heavy metal ions as a new biochemical marker of aquatic environment pollution. Environ. Toxicol. Chem. 2010, 29, 497-500. [CrossRef] [PubMed]

4. Chiou, C.T.; Peters, L.J.; Freed, V.H. A physical concept of soil-water equilibria for non-ionic organic compounds. Science 1979, 206, 831-832. [CrossRef] [PubMed]

5. Karickhoff, S.W.; Brown, D.S.; Scodd, T.A. Sorption of hydrophobic pollutants in natural sediments. Water Res. 1979, 13, 241-248. [CrossRef]

6. Szlauer-Lukaszewska, A. Effects of river bed regulation on habitats and communities: A case study for ostracods in the Oder River, Poland. Int. Rev. Hydrobiol. 2015, 100, 69-78. [CrossRef]

7. Su, J.; van Bochove, E.; Auclair, J.; Theriault, G.; Hu, C.; Li, X. Phosphorus Fluxes at the Sediment-Water Interface in a Temperate Region Agricultural Catchment. Water Air Soil Poll. 2014, 225, 1739. [CrossRef]

8. Vasilyeva, G.K.; Strijakova, E.R. Bioremediation of soils and sediments contaminated by polychlorinated biphenyls. Microbiology 2007, 76, 639-653. [CrossRef]

9. Yang, H.; Li, C.; Zhang, J. Determining roles of in-situ measured surface potentials of phase controlled synthesized $\mathrm{MnO} 2$ nanostructures for superficial adsorption. Appl. Surf. Sci. 2020, 513, 145752. [CrossRef]

10. Tomaszewski, J.E.; Smithenry, D.W.; Cho, Y. Treatment and Containment of Contaminated Sediments. In Assessment and Remediation of Contaminated Sediments; Danny, R., Tomas, L., Eds.; Springer: Dordrecht, The Netherlands, 2006; Volume 73, pp. 137-178.

11. Zimmerman, J.R.; Ghosh, U.; Millward, R.N.; Bridges, T.S.; Luthy, R.G. Addition of carbon sorbents to reduce PCB and PAH bioavailability in marine sediments: Physicochemical tests. Environ. Sci. Technol. 2004, 38, 5458-5464. [CrossRef]

12. Farhadian, M.; Vachelard, C.; Duchez, D.; Larroche, C. In situ bioremediation of monoaromatic pollutants in groundwater: A review. Bioresour. Technol. 2008, 99, 5296-5308. [CrossRef] [PubMed]

13. Miyasaka, T.; Asami, H.; Watanabe, K. Impacts of bioremediation schemes on bacterial population in naphthalene-contaminated marine sediments. Biodegradation 2006, 17, 227-235. [CrossRef] [PubMed]

14. Han, W.; Mao, Y.; Wei, Y.; Shang, P.; Zhou, X. Bioremediation of Aquaculture Wastewater with Algal-Bacterial Biofilm Combined with the Production of Selenium Rich Biofertilizer. Water 2020, 12, 2071. [CrossRef]

15. Kane, A.; Vidumsky, J.; Major, D.W.; Bauer, N.B. In-situ bioremediation of a chlorinated solvent residual source in unconsolidated sediments and bedrock using bioaugmentation. In Contaminated Soils Series; Edward, J.C., Paul, T.K., Eds.; Springer: Boston, MA, USA, 2005; Volume 9, pp. 45-55.

16. Delille, D.; Delille, B.; Pelletier, E. Effectiveness of bioremediation of crude oil contaminated subantarctic intertidal sediment: The microbial response. Microb. Ecol. 2002, 44, 118-126. [CrossRef] [PubMed]

17. Bonardi, M.; Ravagnan, G.; Stirling, J.A.R.; Morucchio, C.; De Sanctis, S. Innovative treatment by bioremediation of contaminated sediments from the Venice Lagoon, Italy: The Arsenale Vecchio case study. J. Coast. Res. 2007, 895-899.

18. Murphy, P.T.; Hall, G.K.; Northcote, G.T. Lime Treatment of a Hardwater Lake to Reduce Eutrophication. Lake Reserv. Manag. 1988, 2, 51-62. [CrossRef]

19. Payne, R.B.; Ghosh, U.; May, H.D.; Marshall, C.W.; Sowers, K.R. A Pilot-Scale Field Study: In Situ Treatment of PCB-Impacted Sediments with Bioamended Activated Carbon. Environ. Sci. Technol. 2019, 53, 2626-2634. [CrossRef]

20. Wang, C.; He, S.; Zou, Y.; Liu, J.; Zhao, R.; Yin, X.; Zhang, H.; Li, Y. Quantitative evaluation of in -situ bioremediation of compound pollution of oil and heavy metal in sediments from the Bohai Sea, China. Mar. Pollut. Bull. 2020, 150, 110787. [CrossRef]

21. Wu, Y.; Lin, H.; Yin, W.; Shao, S.; Lv, S.; Hu, Y. Water Quality and Microbial Community Changes in an Urban River after Micro-Nano Bubble Technology in Situ Treatment. Water 2019, 11, 66. [CrossRef] 
22. Diaz, M.P.; Gringson, S.J.W.; Peppiatt, C.; Burgess, J.G. Isolation and characterization of novel hydrocarbon degrading euryhaline consortia from crude oil and mangrove sediments. Mar. Biotechnol. 2000, 2, 522-532.

23. Bose, D.; Santra, M.; Sanka, V.S.P.R.; Krishnakumar, B. Bioremediation analysis of sediment-microbial fuel cells for energy recovery from microbial activity in soil. Int. J. Energy Res. 2020, 44, 98. [CrossRef]

24. Wang, Q.; Li, Y.; Wang, C.; Wu, Y.; Wang, P. Development of a novel multi-functional active membrane capping barrier for the remediation of nitrobenzene-contaminated sediment. J. Hazard. Mater. 2014, 276, 415-421. [CrossRef] [PubMed]

25. Boopathy, R. Factors limiting bioremediation technologies. Bioresour. Technol. 2000, 74, 63-67. [CrossRef]

26. Hai, T.P.; Hien, T.T.; Linh, T.V.; Hien, T.D.; Thuy, T.T.N.; Thu, H.T.D.; Mai, T.T.N.; Huy, Q.N.; Byung, H.K. A Laboratory-Scale Study of the Applicability of a Halophilic Sediment Bioelectrochemical System for in situ Reclamation of Water and Sediment in Brackish Aquaculture Ponds: Establishment, Bacterial Community and Performance Evaluation. J. Microbiol. Biotechnol. 2019, 29, 1104-1116.

27. Wang, Z.; Gao, M.; Wei, J.; Ma, K.; Zhang, J.; Yang, Y.; Yu, S. Extracellular polymeric substances, microbial activity and microbial community of biofilm and suspended sludge at different divalent cadmium concentrations. Bioresour. Technol. 2016, 205, 213-221. [CrossRef] [PubMed]

28. Zhao, X.; Chen, X.; Dong, D. Study of the Rapid Measurement of COD by Laser-Induced Breakdown Spectroscopy. Spectrosc. Spect. Anal. 2019, 39, 2907-2911.

29. Zhang, N.; Guo, D.; Zhu, Y.; Wang, X.; Zhu, L.; Liu, F.; Teng, Y.; Christie, P.; Li, Z.; Lu, Y. Microbial remediation of a pentachloronitrobenzene-contaminated soil under Panax notoginseng: A field experiment. Pedosphere 2020, 30, 563-569. [CrossRef]

30. Bo, B.; Kim, S.; Han, N.S. Bacterial and fungal diversity in Laphet, traditional fermented tea leaves in Myanmar, analyzed by culturing, DNA amplicon-based sequencing, and PCR-DGGE methods. Int. J. Food Microbiol. 2020, 320, 108508. [CrossRef]

31. Saby, S.; Djafer, M.; Chen, G.H. Effect of low ORP in anoxic sludge zone on excess sludge production in oxic-settling-anoxic activated sludge process. Water Res. 2003, 37, 11-20. [CrossRef]

32. Filcheva, E.; Kotsev, T.; Cholakova, Z.; Chakalov, K.; Popova, T. Content and composition of organic matter in heavy metal polluted alluvial soils from Ogosta River basin. Ecol. Future-J. Agric. Sci. For. Sci. 2011, 10, 30-39.

33. Chen, J.; Lu, S.; Zhao, Y.; Wang, W.; Huang, M. Effects of overlying water aeration on phosphorus fractions and alkaline phosphatase activity in surface sediment. J. Environ. Sci. 2011, 23, 206-211. [CrossRef]

34. Deng, Q.; Su, C.; Lu, X.; Chen, W.; Guan, X.; Chen, S.; Chen, M. Performance and functional microbial communities of denitrification process of a novel MFC-granular sludge coupling system. Bioresour. Technol. 2020, 306, 123173. [CrossRef] [PubMed]

35. Sergienko, N.; Radjenovic, J. Manganese oxide-based porous electrodes for rapid and selective (electro) catalytic removal and recovery of sulfide from wastewater. Appl. Catal. B-Environ. 2020, 267, 118608. [CrossRef]

36. Kurian, S.; Kessarkar, P.M.; Rao, V.P.; Reshma, K.; Sarkar, A.; Pattan, J.N.; Naqvi, S.W.A. Controls on organic matter distribution in oxygen minimum zone sediments from the continental slope off western India. J. Mar. Syst. 2018, 207, 103-118. [CrossRef]

37. Tabla-Hernandez, J.; Hernandez-Ramirez, A.G.; Martinez-Tavera, E.; Rodriguez-Espinosa, P.F.; Mangas-Ramirez, E. Impacts on water quality by in situ induced ozone-oxygen oxidation in a polluted urban reservoir. Sci. Total Environ. 2020, 735, 139364. [CrossRef]

38. Song, T.; Yan, Z.; Zhao, Z.; Jiang, H. Removal of organic matter in freshwater sediment by microbial fuel cells at various external resistances. J. Chem. Technol. Biotechnol. 2010, 85, 1489-1493. [CrossRef]

39. Tao, K.; Liu, X.; Chen, X.; Hu, X.; Cao, L.; Yuan, X. Biodegradation of crude oil by a defined co-culture of indigenous bacterial consortium and exogenous Bacillus subtilis. Bioresour. Technol. 2017, 224, 327-332. [CrossRef]

40. Perez, M.C.; Alvarez-Hornos, F.J.; San-Valero, P.; Gabaldon, C.; Martinez-Soria, V. Evolution of bacterial community in a full-scale biotrickling filter by fluorescence in situ hybridization (FISH). Procedia Eng. 2012, 42, 666-671. [CrossRef]

41. Chen, Q.; Ni, J.; Ma, T.; Liu, T.; Zheng, M. Bioaugmentation treatment of municipal wastewater with heterotrophic-aerobic nitrogen removal bacteria in a pilot-scale SBR. Bioresour. Technol. 2015, 183, 25-32. [CrossRef] 
42. Fayiah, M.; Dong, S.; Li, Y.; Xu, Y.; Gao, X.; Li, S.; Shen, H.; Xiao, J.; Yang, Y.; Wessell, K. The relationships between plant diversity, plant cover, plant biomass and soil fertility vary with grassland type on Qinghai-Tibetan Plateau. Agric. Ecosyst. Environ. 2019, 286, 106659. [CrossRef]

Publisher's Note: MDPI stays neutral with regard to jurisdictional claims in published maps and institutional affiliations.

(C) 2020 by the authors. Licensee MDPI, Basel, Switzerland. This article is an open access article distributed under the terms and conditions of the Creative Commons Attribution (CC BY) license (http://creativecommons.org/licenses/by/4.0/). 